\title{
Maqasid-based Consumer Preference Index for Tawarruq Personal Financing
}

\author{
Hanudin Amin ${ }^{1 *}$, Dwi Suhartanto², Muhammad Ali³ ${ }^{3}$ Mohd Fahmi Ghazali, \\ Hamid Rizal' ${ }^{5}$, Dzuljastri Abdul Razak ${ }^{6}$
}

*) Corresponding e-mail: hanudin@ums.edu.my

Article History

Received: May 29th 2021

Revised: June $13^{\text {th }}, 2021$

September $17^{\text {th }}, 2021$

Accepted: July $29^{\text {th }}, 2021$

\begin{abstract}
Relatively, maqasid al-Shariah is a missing dimension element in the available tawarruq personal financing, resulting in a convergence of this facility and its traditional counterpart. This work examines the consumer preference of tawarruq personal financing using the maqasid-based consumer preference index (MCPi). Drawing upon the $\mathrm{MCPi}$, the present study examines consumer preference on the offered Tawarruq personal financing by 7 Islamic banks in Malaysia based on valid 456 usable questionnaires. The primary findings obtained indicate that all banks somewhat have a moderate MCPi. These include Bank Islam Malaysia Berhad (BIMB), Bank Muamalat Malaysia Berhad (BMMB), Maybank Islamic, CIMB Islamic, RHB Islamic, Kuwait Finance House and Al-Rajhi Bank. This study examines a new approach to measure consumer preference using the MCPi. Our contributions are confined to these particular variables - Educating Customer, Establishing Justice and Promoting Welfare. Our study also limits its perspective on the general context of tawarruq personal financing. Future works may provide different perspectives on these interrogations. This study provides a new index for Islamic banks to manage tawarruq personal financing products according to maqasid al-Shariah effectively. This study introduces a new measure of consumer preference of tawarruq personal financing namely the MCPi in the context of Malaysia.
\end{abstract}

Keywords: Consumer; Maqasid al-Shariah; Islamic financing; Malaysia JEL Classification : D11, D12, D14

Type of paper: Research Paper

@ IJIEF 2022 published by Universitas Muhammadiyah Yogyakarta, Indonesia

DOI:

https://doi.org/10.18196/ijief.v5i1.11823
Web:

https://journal.umy.ac.id/index.php/ijief/article/view/11823

Citation:

Amin, H., Suhartanto, D., Ali, M., Ghazali, M. F., Rizal, H., \&Razak, D. A. (2022). Maqasid-based consumer preference index for tawarruq personal financing. International Journal of Islamic Economics and Finance (IJIEF), 5(1), 1-30. DOI: https://doi.org/10.18196/ijief.v5i1.11823.

\footnotetext{
1 Universiti Malaysia Sabah, Malaysia

2 Bandung State Polytechnic, Indonesia

${ }^{3}$ Institute of Business Management, Pakistan

4 Universiti Kebangsaan Malaysia, Malaysia

${ }^{5}$ Universiti Malaysia Sabah, Malaysia

${ }^{6}$ International Islamic University Malaysia, Malaysia
} 
Amin, Suhartanto, Ali, Ghazali, Rizal, \& Abdul Razak | Maqasid-based Consumer Preference Index for Tawarruq Personal Financing

\section{Introduction}

\subsection{Background}

Providing financial assistance to needy and poor people is an act of virtue that shapes camaraderie among Muslims in return a true brotherhood is built. Of course, every good deed done is compensated by Allah (SWT) and every bad deed is chastised. Since helping needy and poor people financially is a good deed, hence it is rewarded by the Almighty. On top of that, tawarruq personal financing becomes one of the Islamic banking products that contribute to strengthened profitability to Islamic banks as well as its contribution that leads to an increased number of bank customers for an improved customer base. This also articulates to us that Islamic banking has been ingenious in developing new financial products - meeting the Shariah compliancy expectation, where benefits are superior to their cost. From 1983 till today, Malaysian Islamic banks keep on improving their performance and public image through extended financial engineering (Iqbal and Mirakhor, 2011) and tapping into Shariah governance's potential (Muneeza, Hassan and Wisham, 2011; Hassan, 2014). Consequently, Islamic banks remained resilient, competitive and somewhat better than their conventional peers relatively implying Islamic banks are offering financial innovations, which are safe, secured and profitable - competitive when comparing with their conventional counterparts.

Although tawarruq personal financing earned improved Shariah compliancy and being innovative, still there are misconceptions sourced from poor mindsets by laymen who are steering the facility flaws and associated them with the earlier practice of bay al-inah - sale and buy-back arrangement (Ali and Hassan, 2016). Firstly, there is a negative word of mouth, which are somewhat shared on social media platforms and even worse, they were suggesting a total improvement in terms of products' novelty - to be novel without mimicking their conventional peers even this is claimed to be a sentiment and being groundless to be taken. Secondly, there is also a fallacy suggesting that tawarruq personal financing is just a rebranding of bay al-inah personal financing, even though these two are not in tandem in terms of modus operandi and the validity of Shariah compliance. Thirdly, there is also a poor mindset by laymen claiming tawarruq personal financing is similar to its conventional peer, personal loan - claiming this occurs as far as the two have an "increased implication" in terms of the selling price associated with tawarruq personal financing and in terms of unjustified increase with a personal loan. Even, in reality, they are not alike. Without any measures for improvement, these issues can become bigger when the social circle of the laymen become bigger, which lead to poor public image and in turn poor receptiveness. To date, tawarruq personal financing is now not only 
Amin, Suhartanto, Ali, Ghazali, Rizal, \& Abdul Razak | Maqasid-based Consumer Preference Index for Tawarruq Personal Financing

competed with its conventional peer but also qardhul hassan financing, which is available in some particular states in Malaysia. To compete better, Islamic banks should acknowledge the importance of welfare and justice in their offered tawarruq personal financing to be concerning qardhul hassan financing (Ahmed, 2011). These elements somewhat are fallen short, which warrants further attention to improve its marketability.

In general, the bank serves two roles in the tawarruq masrafi (organised tawarruq). The bank serves two functions, firstly, as the customer's purchasing agent, and secondly the customer's selling agent. The problem here is the authenticity of these roles, whether it is existed in reality or only in theory. To ensure tawarruq personal financing occurs Islamically, the transacting commodity must be made available and accessible among the transacting parties to ensure deliverability can take place. If the availability and accessibility are not met, the financing product is invalid. Full ownership should take place before the seller can sell the commodity to the buyer. These issues are only some issues that are drawn from tawarruq personal financing. The selling point here is (1) these issues have a great likelihood to repeat not only to the one bank but also to many banks, when human errors are taken into account (2) these issues are important to be avoided to ensure the Shariah compliancy can be upheld accordingly. Islamicity, transparency, availability and accessibility are deliberately the key.

Many studies in Islamic financing have considered Islamic home financing (Md-Taib, Ramayah and Abdul Razak, 2008), qardhul hassan financing (Amin, Ghazali and Supinah, 2010) and ar-rahnu financing (Amin and Chong, 2011), to mention some. Relatively, studies pertinent to tawarruq personal financing are fallen short. Shreds of evidence pertinent to the factors influencing tawarruq personal financing are somewhat limited, and the best we can share is a study by Amin and Abdul Hamid (2018), which examines factors contributing to the receptiveness of tawarruq home financing though a focus has deviated from the present work. Moreover, earlier works have considered conventional theories in examining factors contributing to the receptiveness of Islamic financing products (Md Taib et al., 2008; Ali, Raza, Puah and Karim, 2017). The theories employed include the Theory of Reasoned Action (TRA), the Theory of Planned Behaviour (TPB), the Diffusion of Innovations Theory (DIT) and the Triandis Interpersonal Behaviour Theory (TIB). The theories employed include the Theory of Reasoned Action (TRA), the Theory of Planned Behaviour (TPB), the Diffusion of Innovations Theory (DIT) and the Triandis Interpersonal Behaviour Theory (TIB). Though valid, these theories are developed in the framework of capitalist norms, which meets one's unrestricted needs in any consumption at the expense of public interest (Khan, 2014) and therefore it is not sufficient to reflect maqasid al-Shariah in 
Amin, Suhartanto, Ali, Ghazali, Rizal, \& Abdul Razak | Maqasid-based Consumer Preference Index for Tawarruq Personal Financing

the context of tawarruq personal financing. The present study is conducted to close the gap that existed.

\subsection{Objective}

This work is aimed at assessing consumer preference of tawarruq personal financing in Malaysia. For that purpose, we apply maqasid al-Shariah to our current context, and we call it the maqasid-based consumer preference index (MCPi). At best, three reasons why maqasid al-Shariah is considered as the theory that leads to the development MCPi. Firstly, maqasid al-Shariah ranks preference according to the hierarchy of basic needs and considering wants is only made when all the magnitude of basic need is met. Secondly, maqasid al-Shariah offers consumption and spending according to Islamic worldview elements, where overspending and wastages are prohibited in any halal decision related to consumption and spending. Thirdly, past studies have proven empirically that maqasid al-Shariah is somewhat valid in examining consumer preference (Amin et al. 2014) and Islamic banking performance (Mohammed, Abdul Razak and Md Taib, 2008). Hence, the maqasid theory is selected.

The MCPi developed here is essentially different from other previous studies' findings in three ways. We first attempt to extend the applicability of Hwang and Yoon's (1981) approach, which is on simple additive, weighting method to the MCPi. It is yet employed in the context of tawarruq personal financing. We second make an effort to employ an interplay approach where the integrations between Abu Zahrah's (1997) theory and Hwang and Yoon's (1981) approach are made possible. The last one is in terms of the development of rare battery items related to the current dimensions' items (Educating the public, Establishing justice and Promoting welfare). In all, this study adds to the very limited knowledge available for literature in the MCPi, and the results obtained can provide a general direction to improve the planning of tawarruq personal financing.

The rest of the paper is organised as follows. In the second section, the background of tawarruq and related previous studies are presented. The third section discusses the research methodology, which outlines the description of the theory used, sample and data collection. The fourth section presents the empirical results, which are aimed at answering the research objective developed earlier. The last section concludes this work. 
Amin, Suhartanto, Ali, Ghazali, Rizal, \& Abdul Razak | Maqasid-based Consumer Preference Index for Tawarruq Personal Financing

\section{Literature Review}

\subsection{Background Theory}

Tawarruq is normally broken down into two categories. Category \#1: Tawarruq haqiqi (tawarruq fardi). In this type of tawarruq, it is assumed that four parties are get involved namely the seller, the bank, the customer and the buyer. The bank purchases commodity XYZ from the seller, and then the bank resells it to the customer (at a mark-up), the customer later will resell it to the buyer for cash. The purpose is for cash or liquidity. No interaction exists between the bank and the last buyer. This is of a classical type. Category \#2: Tawarruq munazzam. Two types of tawarruq derived from it are al-masrafi and reverse tawarruq. Regardless of these types, tawarruq munazzam assumed that four parties are get involved namely the seller, the bank, the customer and the buyer. The bank purchases commodity XYZ from the seller, and then the bank resells it to the customer (at a mark-up), the customer later will appoint the bank to resell it to the buyer for cash. The purpose is for cash or liquidity. There is an interaction between the bank and the last buyer. This is an organised type of tawarruq and it is widely offered by Malaysian Islamic banks as depicted in Table 1.

Table 1. The Offered Islamic Personal Financing in Malaysia

\begin{tabular}{llcc}
\hline No & \multicolumn{1}{c}{ Islamic Bank } & Tawarruq & Bay al-Inah \\
\hline 1 & Affin Islamic Berhad & Yes & No \\
2 & Al Rajhi Bank & Yes & No \\
3 & Alliance Islamic Berhad & Yes & No \\
4 & AmBank Islamic & No & Yes \\
5 & Bank Islam Malaysia Berhad & Yes & No \\
6 & Bank Muamalat Malaysia Berha & Yes & No \\
7 & CIMB Islamic & Yes & No \\
8 & Hong Leong Islamic & Yes & No \\
9 & HSBC Amanah & Yes & No \\
10 & Kuwait Finance House & Yes & No \\
11 & Maybank Islamic Berhad & Yes & No \\
12 & MBSB Bank & Yes & No \\
13 & OCBC Al Amin & Na & Na \\
14 & Public Islamic Berhaad & No & Yes \\
15 & RHB Islamic Bank & Yes & No \\
16 & Standard Chartered Saadiq & Yes & No \\
\hline
\end{tabular}

Note: $\mathrm{Na}=$ not available

To explicate tawarruq personal financing, an example that is derived from Bank Islam Malaysia Berhad (BIMB) is provided. It is denoted as BIMB personal financing. By definition, BIMB personal financing facility is a financing facility in which it is extended to customers to fulfil their genuine financial need, 
Amin, Suhartanto, Ali, Ghazali, Rizal, \& Abdul Razak | Maqasid-based Consumer Preference Index for Tawarruq Personal Financing

where the purposes are identified to Shariah-compliant like for umrah, marriage and visiting family members. The rate used is known as base rate (BR) and it is optionally - be it fixed or floating. It is termed "unsecured financing" since there is no requirement for guarantors or items attended as collateral security. The bank relies on $5 \mathrm{Cs}$ in reimbursing cash out of the personal financing to the customer.

The modus operandi of the BIMB personal financing has occurred at least at 7 stages. The details are provided as follows:

S1: The customer applies and completes the form and the necessary documents. The customer signs the agreement Offer to Purchase (OTP) to buy a commodity that is sold to him without knowing the quantity and type of commodity. The completed form is considered ijab to complete the rukun sighah in a sale transaction. This takes a minimum of 3 days and a maximum of 14 days;

S2: The bank will buy the commodity in bundle from Broker $A$ in the international market to meet the financing application which includes murabahah transaction in its 130 branches. This includes personal financing product, business financing etc. It is noted the bank is only allowed to own the commodity for a maximum of 2 hours;

S3: Once it is bought, the bank immediately sells the commodity to the customer on a murabahah basis (mark-up);

S4: The customer, in turn, appoints the bank as an agent through the appointment of the bank as a sale agent (ABSA) to sell back the commodity to Broker B. The appointment is important because the customer is unable to find a new commodity purchaser. The appointment is done at the first stage to facilitate customers from not approaching the bank frequently;

S5: The bank as a representative of the customer will sell the commodity to Broker B at the purchase cost. The transactions involving stage 3 to stage 5 should be done in a period of a maximum of 2 hours;

S6: The proceeds (i.e. equal to the amount applied for personal financing) from Broker B will be credited to the customer's account after the customer signs the acceptance of purchase (AOP) which is viewed qabul. This process is done within a minimum of 24 hours and a maximum of 3 days. At this stage, the customer will identify the selling price of the commodity he bought from the bank; and

S7: The customer pays the selling price on a monthly instalment until maturity. 
Amin, Suhartanto, Ali, Ghazali, Rizal, \& Abdul Razak | Maqasid-based Consumer Preference Index for Tawarruq Personal Financing

The abovementioned happened in practice for Shariah compliance and marketability of the product. Likewise, compounding interest is forbidden in tawarruq personal financing. This type of riba is best known as riba aljahiliyyah out of penalty or extra payment once a debtor is unable to service the loan on time. In our context, however, accumulated ta'widh is allowed out of compensation issue at a fixed rate of 1 per cent.

\subsection{Previous Studies}

Studies in the area of Islamic personal financing including tawarruq personal financing have been developed in four primary topics but are not limited to the practical context, theory testing and market survey and maqasid-based consumer behaviour, to mention some. The details are provided.

\subsubsection{Practical perspectives}

Dusuki (2010) offers a point of view analysis pertinent to tawarruq financing products through the introduced Bursa Suq al Sila in 2009 in which is a platform that facilitates Islamic financial transactions mainly tawarruq financing products including personal financing. The market provides genuine commodity transactions where possession and delivery of the commodity can take place without any hindrance, as opposed to the controversial practice of tawarruq using the London Metal Exchange. Bursa Suq al Sila provides improved Shariah compliance which leads to a declaration by OIC Fiqh Academy deems as impermissible. Unlike Ab Rahman, Mohamad and Salleh (2010), this study is the first of its kind to provide a macro perspective of the tawarruq practices in Malaysia.

Ab Rahman et al. (2010) examine bay al-tawarruq and its application at Bank Islam Malaysia Berhad's (BIMB) personal financing. The practice is built based on tawarruq munazzam or organised tawarruq. Unlike Mahyudin and Che Seman (2014; 2018) and Alkhan and Hassan (2019), Ab Rahman et al. (2010) offer three interesting rulings pertinent to the permissibility of bay altawarruq. First, bay al-tawarruq is viewed to be permissible (harus), second it is reprehensible (makruh) and thirdly it is reprehensive nearing prohibited (makruh closes to haraam). Detail differences between bay al-inah and bay al-tawarruq are offered significantly. One of the differences is that the number of parties involved for the former is only two persons whilst the latter considers three parties and more. Generally, this study influences other authors, in explaining the practical use of bay al-tawarruq (Abdullah Thaidi et al., 2014; Mahyudin and Che Seman, 2014; 2018; Alkhan and Hassan, 2019).

Abdul Rahman and Ab Manan (2014) examine tawarruq as a useful instrument to finance retail the halal (permissible) way. Any types of business running are considered halal not only in terms of the products and services sold to 
Amin, Suhartanto, Ali, Ghazali, Rizal, \& Abdul Razak | Maqasid-based Consumer Preference Index for Tawarruq Personal Financing

consumers but also in how they are funded. If the funds obtained are emanated from halal financing, then it is considered Shariah-compliant. Generally, speaking the efforts taken by Abdul Rahman and Ab Manan (2014) are relatively comparable to other works (Ab Rahman et al., 2010) and nothing new offered but sufficient for public reading. Though limited, this work intends to promote tawarruq personal financing as a financing method for helping Muslim businesses to strengthen their businesses in terms of customer base and profit earned. This notion has influenced Ahmad, Shihama, Mohamad Tarmizi, Jibril, Djama and Muneeza (2017) who acknowledge that bay al-inah has a problem due to legal stratagem, and for that tawarruq is introduced as a replacement. Detail descriptions about Bursa Suq Al Sila are offered meticulously which helps improve our understanding concerning its practice and application.

Influenced by Ab Rahman et al. (2010), Abdullah Thaidi, Ab Rahman and Ab Rahman (2014) provide further exposition pertinent to tawarruq personal financing, where the emphasis is given on the existence of uncertainty (gharar) in each stage of transactions. This focus if we compare with other works (e.g. Alkhan and Hassan, 2019), has been distinct in divulging the beauty of Shariah compliance of the facility. Using library observation and qualitative interviews, this study finds out that there is a gharar element in the practice of tawarruq personal financing. It is permitted out of gharar yasir termed as little or small gharar. The first gharar is on the exact details of the transacting commodity for the selling transaction when a customer is applying for the facility. The second is about the selling price that is determined at the beginning of the transaction, which is not informed to the customer in the ijab process. The third is about the running of the aqad (ijab and qabul), which is done simultaneously in one session. This has happened when a customer signs OFFER TO PURCHASE (OTP) at the beginning and then the qabul takes place after at least a minimum of three days when the customer signs the ACCEPTANCE OF PURCHASE (AOP). ljab and qabul are done separately and not in one session. These details are missing in other works (Mahyudin and Che Seman, 2014; 2018; Alkhan and Hassan, 2019) out of considered different research scope and paradigm.

Drawn from Mahyudin and Che Seman (2018), specific information pertinent to bay al-tawarruq in Bank Muamalat Malaysia Berhad (BMMB) is provided. In more detail, they examine the original principles and current application of the tawarruq in the context of BMMB. Tawarruq has been adopted as an alternative to the bay al-inah in financing products offered by BMMB. It was departed in 2006 at the bank and unlike bay al-inah it is considered a less controversial contracts. All BMMB financing products including personal financing followed tawarruq have been executed properly according to the sequences in tandem with the Shariah committee but somehow such 
Amin, Suhartanto, Ali, Ghazali, Rizal, \& Abdul Razak | Maqasid-based Consumer Preference Index for Tawarruq Personal Financing

practices may vary for deposit products accordingly. Earlier, the same authors also made an attempt pertinent to bay al-tawarruq at the same bank. Mahyudin and Che Seman (2014) find bay al-tawarruq has replaced bay alinah in operationalising financing products of the bank and such a finding is emanated from interview among staff to support the study's library research. Jointly, due to legal trick (hilah), tawarruq personal financing is viewed as the best to replace bay al-inah personal financing which has acute problem pertinent to hilah, which is reported inconvenience and unIslamic.

Unlike Mahyudin and Che Seman (2014; 2018), Alkhan and Hassan (2019) provide an interesting debate pertinent to the permissibility of the product. Generally, they report that the practice of organised tawarruq as found in the context of personal financing might be permissible according to Shariah. Furthermore, four main mistakes drawn from the engaged organized tawarruq are but not limited to. The client delegates the Islamic bank to sell the commodity on his behalf, the Islamic bank appointing an agent on behalf of the client - so that the agent may sell the commodity on behalf of the client, lack of existence of a commodity and selling the same commodity to multiple Islamic banks simultaneously. The study discovers the practice of organised tawarruq has been in adherence to Shariah and according to AAOIFI Shariah standards, especially when organised tawarruq transactions are executed for Islamic personal financing.

\subsubsection{Theory Testing}

Past works in Islamic financing products have rotated in three main theories, the Theory of Reasoned Action (TRA), the Theory of Planned Behaviour (TPB) and the Rogers' Innovation Diffusion Theory (IDT), to mention some. A study by Amin et al. (2010) examines factors determining qardhul hassan financing acceptance using the TRA and discovers subjective norm, pricing and attitude influence the acceptance. Unlike Amin et al. (2010), Amin, Abdul Rahman and Abdul Razak (2014) examine factors determining Islamic home financing using the TPB. They managed to discover the significant relationships between attitude, subjective norm, perceived behavioural control, Islamicity of product and acceptance. Besides, marital status, ethnicity, occupation and religion are also instrumental in determining acceptance. Such demographic items are untapped in Amin et al. (2010) due to different research scope and objective. Unlike Amin et al. (2010) and Amin et al. (2014), Amin, Abdul Rahman and Abdul Razak (2013) examine Islamic home financing acceptance using an integrative approach, through a combined framework sourced from the TPB and the IDT. This integrative approach helps improve the explanatory powers emanated from the factors concerned and provides more rich empirical results, which are strengthened if compared with one theory used. 
Amin, Suhartanto, Ali, Ghazali, Rizal, \& Abdul Razak | Maqasid-based Consumer Preference Index for Tawarruq Personal Financing

Amin et al. (2013) report that attitude, compatibility, subjective norm, reliability advantage simplicity and perceived behavioural control affect Islamic home financing acceptance. It is worth mentioning that the factors determining the acceptance are relatively broad that may justify the importance of amalgamating theories to have an extended result. Earlier work in Islamic home financing acceptance like Md Taib et al. (2008) only examine attitude and subjective norm drawn from the TRA and found both are statistically significant. Their findings however confined our abilities to observe what are other factors determining the behavioural intention. All these reviewed studies provide a point of departure pertinent to the theoretical framework and how it is relevant to the current context. First, consumer theories used when studying consumer acceptance, consumer behaviour are driven by conventional theories which have a different definition of worldviews in consumption and spending - limited to the worldly needs only. Second, limited efforts have forwarded by these studies in examining tawarruq personal financing, perhaps it is a replacement product that is still at the infancy stage in Malaysia. The only study-related is by Amin and Rizal (2018) who examine tawarruq but from the context of Islamic mortgages, and due to this considered outcome, the current work is extending to void the research gap found.

\subsubsection{Market Survey}

Ali and Hassan (2016) examine the issue of Shariah non-compliant events in Islamic banks in the practice of tawarruq financing in Malaysia. Drawing from a qualitative methodology, they managed to elicit responses from 16 Malaysian Islamic banks pertinent to the Shariah non-compliance issue. They report that some practices of tawarruq financing have been at an alarming rate and may need corrective measures to ensure its Shariah compliance. In more detail, the study discovers an improper sequence of sale contracts, improper facility disbursement, improper disclosure of price, the absence of wakalah agreement, inappropriate imposition of ta'wid (compensation and delivery restriction, among others, contribute to the Shariah non-compliant events. Importantly, non-halal income sourced from these events is channelled to the poor, underserved, da'wah (Islamic propagation) and school-related activities.

On the same note, Ali and Hassan (2020) examine determinants of Shariah non-compliant events in Islamic banks in Malaysia, where tawarruq financing comes into play. Unlike Ali and Hassan (2016), Ali and Hassan (2020) offer further elaborations on tawarruq through the presentation of the determinants, which are untapped in Ali and Hassan (2016) though emanated from the same authors. They discover that lack of understanding and knowledge, inadequate control mechanism, ineffective functional structure, 
Amin, Suhartanto, Ali, Ghazali, Rizal, \& Abdul Razak | Maqasid-based Consumer Preference Index for Tawarruq Personal Financing

incompatibility of system, improper document execution and inadequate internal policies have led to Shariah non-compliant events. Without any measure, Shariah non-compliant events can accelerate negative perception, which in turn can create new sentiment to reject tawarruq personal financing, for instance.

\subsubsection{Maqasid-based Consumer Behaviour}

Ahmed (2011) provides a relevant argument pertinent to the maqasid alShariah quality for the offered Islamic banking products available around the world. The important contribution of his work is the proposal of exposing three types of Islamic financial products sourced from two sets of Shariah requirements built, one legal and other social obligations. The first product is a Shariah-based product that is meeting both legal and social obligations. The second product is a Shariah-compliant product that is meeting the only legal requirement at the expense of social obligations. The third product is a pseudo-Islamic product that meets the form but not the substance of Islamic law. Maqasid is related to Islamic financial products in two dimensions. First, SSB is responsible to ensure the maqasid is achieved the contract level by fulfilling the form and substance of Islamic law. Second, BOD determines whether the products are Shariah-based or Shariah-compliant - along with the line, the SSB observes and ensures the products are not pseudo-Islamic to attain maqasid al-Shariah. Unlike Ahmed (2011), a study by Amin (2017) examines consumer behaviour from a standpoint of the Islamic Theory of Islamic consumer Behaviour (ITCB) and one of the variables used is perceived maqasid. The study finds a significant relationship between perceived maqasid and consumer behaviour, sourced from unbiased respondents' feedbacks as well as the proper process involved in developing their battery items reflecting the maqasid. Influenced by Khan and Ghifari (1992), Amin (2017) develops a framework for prediction and applications in future work of any prospective researchers. Khan and Ghifari (2017) assert that the consumption which is driven by maqasid al-Shariah is potentially conducted according to hierarchy - ranging from essential (daruriyyat), complementary (hajiyyat) and embellishment (tahsiniyyat). One is meeting first the essential before the second two follow.

The issue of maqasid al-Shariah in ensuring the Shariah compliancy of Islamic banking products including tawarruq personal financing has been also addressed by Bakar (2016) in his published work Shariah minds in Islamic finance. Following Bakar (2016), maqasid al-Shariah does not invalidate the Shariah contracts used in Islamic financing products and is not considered a ruling in justifying the modus operandi of the products. Maqasid al-Shariah provides new perspectives about the products' fulfilment based on the elements of life, religion, intellect, property and lineage, and therefore it is 
Amin, Suhartanto, Ali, Ghazali, Rizal, \& Abdul Razak | Maqasid-based Consumer Preference Index for Tawarruq Personal Financing

reasonable to consider its relevance to the offered tawarruq personal financing and surely it does not invalidate the product when it is not applied. Further, Amin (2019) examines consumer acceptance using a maqasid alShariah approach. Unlike Khan and Ghifari (1992) and Amin (2017), Amin (2019) explains the behaviour based on three factors sourced from the maqasid stance, namely education, welfare, justice and debt policy. These factors are instrumental in determining the receptiveness - hence extending the applicability of the maqasid al-Shariah to include consumer receptiveness of mortgage-based Islamic social finance. This study develops a source of funding drawn from zakat, waqf and sadaqah for promoting affordable mortgage financing. Earlier, a work by Amin and Abdul Hamid (2018) learn to promote tawarruq home financing, where the source of funding derived from Islamic banks' shareholder funds as well as reserves. Their finding is in tandem with Amin's (2017) findings obtained - demonstrating the quality of maqasid compliance is nothing but a significant predictor. Bank customers' intent to patronise tawarruq home financing should the incentives of justice, welfare and education are established for a formation of willingness to accept.

All in all, three important summaries are drawn from the studies reviewed. Firstly, past studies have addressed tawarruq personal financing from the context of permissibility of the offered at the marketplace (Alkhan and Hassan, 2019; Mahyudin and Che Seman, 2014; 2018; Ahmad et al., 2017; Abdul Rahman and Ab Manan, 2012). This issue, so far, has been settled when Bursa Suq al Sila introduced in 2009 to overcome that issue, where Shariah compliance is brought into play. Secondly, we acknowledged that limited efforts are documented on how existing theories relevant to tawarruq personal financing in terms of public perception and receptiveness (Amin et al., 2013; Md-Taib et al., 2008). This also another question, which warrants an empirical investigation as evidently found in the present study. Thirdly, what remains a puzzle is on how maqasid al-Shariah can really useful to gauge consumer preference and for that purposes we attempt to develop constructs' items to close the gap (Ahmed, 2011; Khan and Ghifari, 1992).

\section{Methodology}

Our index is called Maqasid Consumer Preference Index (MCPi) consists of Educating Customer (EC), Establishing Justice (EJ) and Promoting Welfare (PW) and the intra-attributes are the 20 elements and the 20-Consumer Behaviour Measure (CBM). The weights for the 3 dimensions of the MCPi and the 20 elements are evaluated by five Shariah scholars. The evaluation for the CBM is based on consumers' response to the 7 sampled Islamic banks in Malaysia. The model specification involving the four indexes is described as follows: 
Amin, Suhartanto, Ali, Ghazali, Rizal, \& Abdul Razak | Maqasid-based Consumer Preference Index for Tawarruq Personal Financing

$$
\begin{aligned}
& \mathrm{V}(01-03)=W \frac{1}{1} \times E \frac{1}{1} \times R \frac{1}{1}+W \frac{1}{1} \times E \frac{2}{1} \times R \frac{2}{1}+W \frac{1}{1} \times E \frac{3}{1} \times R \frac{3}{1}+W \frac{1}{1} \times E \frac{4}{1} \times R \frac{4}{1}+ \\
& W \frac{1}{1} \times E \frac{5}{1} \times R \frac{5}{1} \\
& \text { OR } W \frac{1}{1}\left(E \frac{1}{1} \times R \frac{1}{1}+E \frac{2}{1} \times R \frac{2}{1}+E \frac{3}{1} \times R \frac{3}{1}+E \frac{4}{1} \times R \frac{4}{1}+E \frac{5}{1} \times R \frac{5}{1}\right)
\end{aligned}
$$

The weightage assigned to each component of MCPi is based on the five Shariah scholars' feedback pertinent to the level of relevance of the components involved in the context of tawarruq personal financing. The first component, Educating customer rated 33 per cent and the same score extended to Establishing justice. Promoting welfare is rated 34 per cent. The categorisation of the MCPi into three categories (low, moderate and high) is based on its maximum value of 5 . The categories are broken down into three groups namely Low (<3.00), Moderate (3.00 - 3.75), and High (3.76 and above) and these categories are agreed by the Shariah scholars

The total of the Consumer Measures for the MCPi for each bank formed the MCPi, implying that the MCPi for the individual bank is the sum of its CBM of $E C, E J$ and PW, thus:

$$
\mathrm{MCPi}=\mathrm{EC}(01)+\mathrm{EJ}(02)+\mathrm{PW}(03)
$$

As noted earlier, the score obtained by an individual bank is defined as follows: Low (<3.00), Moderate (3.00 - 3.75), and High (3.76 and above).

\subsection{Data}

The present study conducts a pilot test involving 30 actual bank customers drawn from Malaysian public universities to elicit their responses to the research instrument. Given the outcome of the test, a revision is made to the research instrument in terms of clarity, format, and presentation. The 
Amin, Suhartanto, Ali, Ghazali, Rizal, \& Abdul Razak | Maqasid-based Consumer Preference Index for Tawarruq Personal Financing

participants in this study are university employees who are also bank customers. They are selected using judgmental sampling method. In Malaysia at least, university staff are asked by their finance department to open savings account for salary crediting, making them part of the customer base of Islamic banks. University employees are diverse according to their grade, age and position, to mention some. Such differences are also found among bank customers, hence, representing the actual composition of Islamic bank customers.

Following Cochran (1963), the present study employs the minimum sample size of 384 with a 5 per cent margin of error and a 95 per cent confidence level. A 5 per cent margin of error is an acceptable margin of error in social studies such as consumer behaviour. In our study, however, customers are derived from a diverse economic background and for that, larger sample size is needed to reflect the heterogeneity of a population. Of the 500 questionnaires, this collects 456 usable questionnaires, which are sufficient at attaining the robust findings. The data collection process is explained as follows:

\section{Step 1: Distributing 500 samples}

There are at least two reasons for selecting 500 samples. First, with a large sample, a small error, which could be generated by some respondents, would have only a small effect on the overall sample results. Second, the sample is more representative of a population, which, in turn, can generate significant outcomes.

\section{Step 2: Selecting Labuan and Kota Kinabalu}

The tawarruq personal financing is also developed obviously in Labuan and Kota Kinabalu in East Malaysia. Labuan is an offshore financial centre whilst Kota Kinabalu is the heart of the domestic banking market in the region.

\section{Step 3: Selecting respondents}

The respondents of this study are drawn from universities located in the selected geographies. University employees are a worthy blend of professional and non-professional groups to represent the actual composition of Islamic bank customers. This study proposes three criteria when selecting the respondents as follows: (1) The respondents are existing Islamic banks' customers; (2) The respondents chosen are aged between 25 to 45 years old; and (3) The respondents are familiar with the offered tawarruq personal financing. 
Amin, Suhartanto, Ali, Ghazali, Rizal, \& Abdul Razak | Maqasid-based Consumer Preference Index for Tawarruq Personal Financing

\subsection{Model Development}

The following are two steps taken to develop the MCPi:

Step \#1 - Literature analyses

After careful consideration, Abu Zahrah's (1997) dimensions are employed due to the growing empirical support as proven by Mohammed et al.'s (2008) research. The authors propose an innovative method to gauge Islamic banks' performance using the maqasid approach, which is found to be empirically valid and reliable. Following Mohammed et al.'s (2008) research, the present study extends the maqasid approach to examine consumer preference and to rank 16 Islamic banks according to customers' feedback based on the MCPi.

Step \#2 - Operationalisation

The present study's battery items are identified in the literature and subsequently verified by Shariah scholars for face validity to produce better items' operationalisation. Table 2 presents the final research instrument.

This study defines the dimensions used as follows, including an explanation of their importance: (1) Educating Customer refers to a consumer's belief that an Islamic bank educates its customers on the offered tawarruq personal financing. With better financial knowledge, bank customers will have improved confidence and willingness to patronise the facility; (2) Establishing Justice refers to a consumer's belief that an Islamic bank promotes fair dealings in its products. Justice assures that the transactions involving the products are impartial and leave bank customers with peace of mind; and (3) Promoting Welfare refers to a consumer's belief that an Islamic bank provides affordable financing products to the needy and poor people. Welfare ensures that people can own houses to improve their well-being.

Based on five series of interviews, the Shariah scholars are asked to assign weights to the dimensions and evaluate whether the CBM measures are acceptable. Table 3 presents the details of the average weights given by scholars.

Table 3 displays that the allocation of weight for each dimension is found to be equal. This denotes that all dimensions tested have similar importance towards the MCPi. Besides, all elements under the dimensions are weighted equally, implying that they have a similar role in representing the MCPi. Based on this finding, it is noted that Islamic banks should rely on multi-dimensional measures rather than individual measure when operating maqasid al-Shariah in their tawarruq personal financing. Besides, our MCPi is best captured by the following visual framework, Figure 1. 
Amin, Suhartanto, Ali, Ghazali, Rizal, \& Abdul Razak | Maqasid-based Consumer Preference Index for Tawarruq Personal Financing

Table 2. Operationalisation

\begin{tabular}{|c|c|c|c|c|}
\hline Concepts & Dimensions & Elements & The MCPi & Data \\
\hline \multirow{5}{*}{$\begin{array}{l}\text { Educating } \\
\text { customer } \\
\text { (Amin et al., } \\
\text { 2014; } \\
\text { Mohammed } \\
\text { et al., 2008) }\end{array}$} & $\begin{array}{l}\text { Knowledge } \\
\text { dissemination }\end{array}$ & Vivid fatwa & $\begin{array}{l}\text { I believe that Islamic banks provide clear } \\
\text { fatwa information for tawarruq personal } \\
\text { financing products }\end{array}$ & Survey \\
\hline & & Clear adverts & $\begin{array}{l}\text { I believe that Islamic banks provide clear } \\
\text { adverts for tawarruq personal financing } \\
\text { products }\end{array}$ & Survey \\
\hline & Publicity & $\begin{array}{l}\text { Continuous } \\
\text { publicity }\end{array}$ & $\begin{array}{l}\text { I believe that Islamic banks provide } \\
\text { continuous publicity for tawarruq } \\
\text { personal financing products }\end{array}$ & Survey \\
\hline & $\begin{array}{l}\text { Islamic } \\
\text { consumerism }\end{array}$ & $\begin{array}{l}\text { Consumer } \\
\text { education }\end{array}$ & $\begin{array}{l}\text { I believe that Islamic banks provide a } \\
\text { consumer education for Tawarruq } \\
\text { personal financing products }\end{array}$ & Survey \\
\hline & & $\begin{array}{l}\text { Product } \\
\text { disclosure } \\
\text { sheet }\end{array}$ & $\begin{array}{l}\text { I believe that Islamic banks provide } \\
\text { sufficient disclosure for tawarruq } \\
\text { personal financing products }\end{array}$ & Survey \\
\hline \multirow{5}{*}{$\begin{array}{l}\text { Establishing } \\
\text { justice } \\
\text { (Mohammed } \\
\text { et al., 2008; } \\
\text { Muneeza et } \\
\text { al., 2011) }\end{array}$} & Unfairness & $\begin{array}{l}\text { Avoidance of } \\
\text { conflict }\end{array}$ & $\begin{array}{l}\text { I believe that Islamic banks have avoided } \\
\text { unfair conflicts with customers of } \\
\text { tawarruq personal financing products }\end{array}$ & Survey \\
\hline & Fair price & $\begin{array}{l}\text { Fairness in } \\
\text { pricing }\end{array}$ & $\begin{array}{l}\text { I believe that Islamic banks have } \\
\text { practised price fairness for tawarruq } \\
\text { personal financing products }\end{array}$ & Survey \\
\hline & $\begin{array}{l}\text { Shariah- } \\
\text { compliant }\end{array}$ & $\begin{array}{l}\text { Islamic } \\
\text { contract }\end{array}$ & $\begin{array}{l}\text { I believe that Islamic banks have offered } \\
\text { a fair contract of tawarruq personal } \\
\text { financing products }\end{array}$ & Survey \\
\hline & & $\begin{array}{l}\text { Shariah } \\
\text { ruling }\end{array}$ & $\begin{array}{l}\text { I believe that Islamic banks have } \\
\text { considered Shariah as a comprehensive } \\
\text { law for tawarruq personal financing } \\
\text { products }\end{array}$ & Survey \\
\hline & & $\begin{array}{l}\text { Free } \\
\text { negative } \\
\text { elements }\end{array}$ & $\begin{array}{l}\text { I believe that Islamic banks have } \\
\text { practised tawarruq personal financing } \\
\text { products that free from negative } \\
\text { elements like riba }\end{array}$ & Survey \\
\hline $\begin{array}{l}\text { Promoting } \\
\text { welfare } \\
\text { (Haniffa \& } \\
\text { Hudaib, } \\
\text { 2007; }\end{array}$ & $\begin{array}{l}\text { Customer } \\
\text { service }\end{array}$ & $\begin{array}{l}\text { Welfare } \\
\text { through an } \\
\text { improved } \\
\text { customer } \\
\text { service }\end{array}$ & $\begin{array}{l}\text { I believe that Islamic banks have } \\
\text { guarded the welfare of customers via } \\
\text { effective customer service }\end{array}$ & Survey \\
\hline $\begin{array}{l}\text { Mohammed } \\
\text { et al., 2008) }\end{array}$ & $\begin{array}{l}\text { Ummah } \\
\text { benefit }\end{array}$ & $\begin{array}{l}\text { Offering } \\
\text { profitable } \\
\text { Islamic } \\
\text { home } \\
\text { financing } \\
\text { products }\end{array}$ & $\begin{array}{l}\text { I believe that Islamic banks have } \\
\text { offered tawarruq personal financing } \\
\text { products that benefit the public } \\
\text { more }\end{array}$ & Survey \\
\hline
\end{tabular}

International Journal of Islamic Economics and Finance (IJIEF), 5(1), 1-30| 16 
Amin, Suhartanto, Ali, Ghazali, Rizal, \& Abdul Razak | Maqasid-based Consumer Preference Index for Tawarruq Personal Financing

Table 2. Operationalisation (Continue)

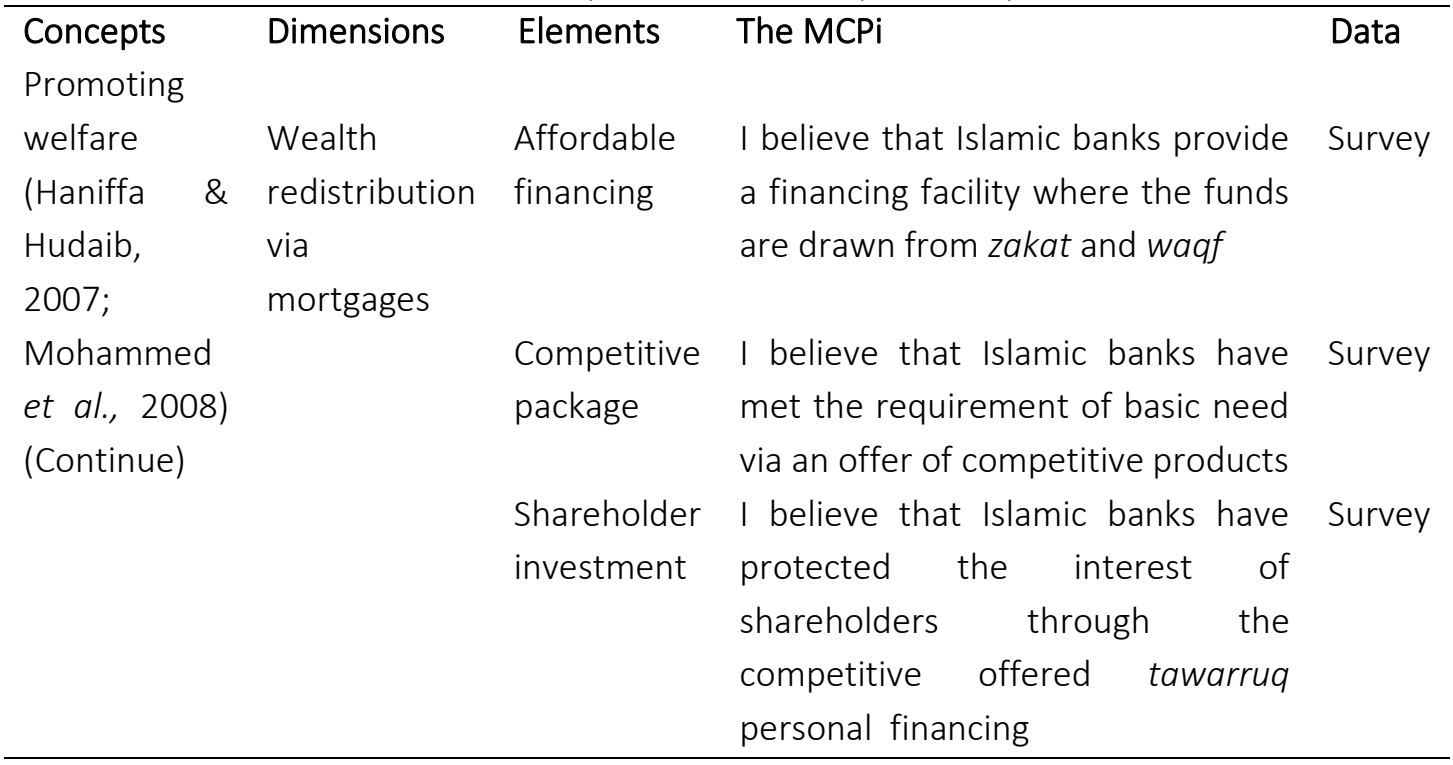

Table 3. Average Weights for the Four and 20 Elements given by Shariah Scholars

\begin{tabular}{|c|c|c|c|}
\hline Concepts & Dimensions & Elements & Weight (100\%) \\
\hline \multirow[t]{5}{*}{ Educating customer } & & E1.Vivid fatwa & 20 \\
\hline & & E2.Clear adverts & 20 \\
\hline & $33 \%$ & E3.Continuous publicity & 20 \\
\hline & & E4.Consumer education & 20 \\
\hline & & E5.Product disclosure sheet & 20 \\
\hline \multirow[t]{5}{*}{ Establishing justice } & & E1.Avoidance of conflict & 20 \\
\hline & & E2.Fairness in pricing & 20 \\
\hline & $33 \%$ & E3.Islamic contract & 20 \\
\hline & & E4.Shariah ruling & 20 \\
\hline & & E5.Free negative elements & 20 \\
\hline \multirow[t]{5}{*}{ Promoting welfare } & & $\begin{array}{l}\text { E1.Welfare through an } \\
\text { improved customer service }\end{array}$ & 20 \\
\hline & $34 \%$ & $\begin{array}{l}\text { E2.Offering profitable tawarruq } \\
\text { personal financing products }\end{array}$ & 20 \\
\hline & & E3.Affordable financing & 20 \\
\hline & & E4.Competitive package & 20 \\
\hline & & E5.Shareholder investment & 20 \\
\hline
\end{tabular}


Amin, Suhartanto, Ali, Ghazali, Rizal, \& Abdul Razak | Maqasid-based Consumer Preference Index for Tawarruq Personal Financing

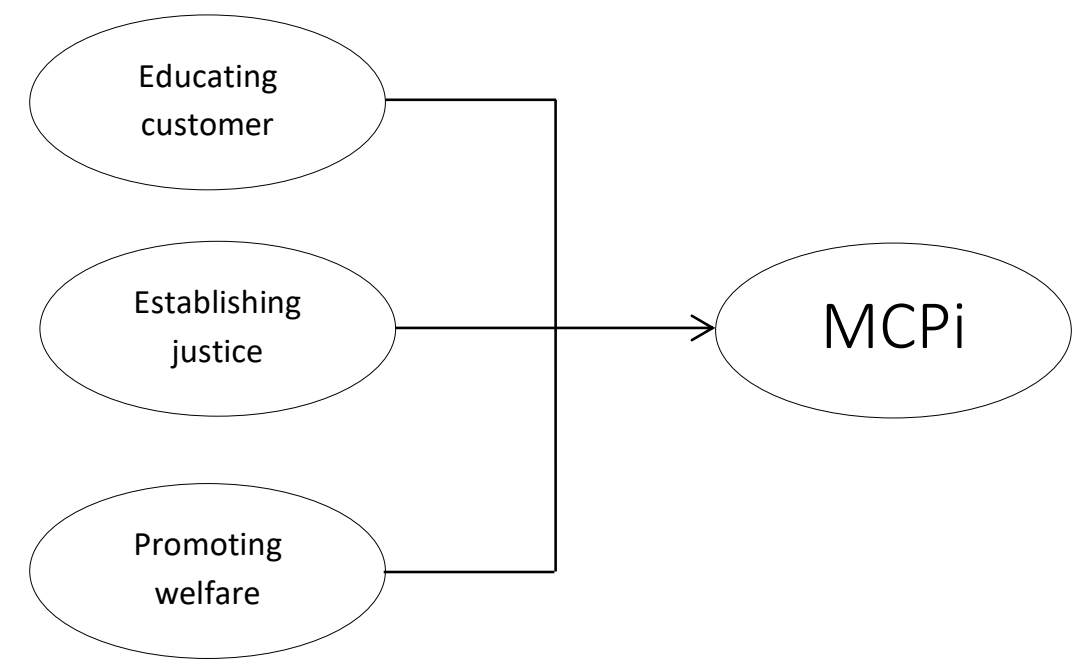

Figure 1. Research Model

\subsection{Method}

The data collected are analysed using the Statistical Package for the Social Sciences (SPSS) 21 due to its flexibility and aptitude to key in large data systematically as a dataset. SPSS is useful for data transformations, particularly when converting data obtained from Microsoft Excel and online questionnaire feedbacks into a readable SPSS dataset. The responses obtained are keyed in by stages to include five battery items for each dimension.

The procedures employed are described as follows: (1) We begin by keying in the items representing 'Educating Customers', followed by 'Establishing Justice', and 'Promoting Welfare'. All items keyed in are obtained from consumer feedbacks. Then, we multiply the weight of $20 \%$ for each item tested based on the equation noted earlier ( $\left.E^{*} C B M\right)$ using a special feature of "Compute Variable" found in the SPSS; and (2) The outcome obtained would be multiplied by $33 \%$ weight as identified in the interview, referring to $33 \%$ $(20 \% * \mathrm{CBM})$. The last stage is the generation of the overall mean scores for the three dimensions to compare the rank of the 7 Islamic banks involved to allow an inference.

\section{Results and Analysis}

\subsection{Results}

The present study conducts a factor analysis using Principal Component Analysis (PCA) to confirm the constructs' item validity (Sekaran \& Bougie, 
Amin, Suhartanto, Ali, Ghazali, Rizal, \& Abdul Razak | Maqasid-based Consumer Preference Index for Tawarruq Personal Financing

2010). The Kaiser-Meyer-Olkin (KMO) Test shows a value of 0.944, indicating that the sampling adequacy is greater than 0.5 , and therefore, is deemed acceptable. Table 4 displays that all constructs' items are loaded greater than the threshold value of 0.6 in the dimension, confirming construct validity.

Concerning Cronbach's alpha, all factors tested have values exceeding the threshold of 0.6 , clarifying that all constructs' items are reliable. The results are as follows: Educating Customer 0.880 (5), Establishing Justice 0.883 (5) and Promoting Welfare 0.904 (5).

To meet the research objective, the MCPi results are presented in Table 5. Concerning Educating Customer, it is reported that Bank Islam Malaysia Berhad has an index score of 3.83 for the first spot, followed by CIMB Islamic, Bank Muamalat and Al-Rajhi Bank, to mention some. The reasons are twofold. First, the banks have disseminated their product information consistently through brochures and bunting; and second, the banks have offered improved customer services to enhance customer satisfaction and patronage.

Educating Customer serves as an opportunity to convert customers' request on tawarruq personal financing into actual demands as affirmed by Amin et al. (2014), who report a positive impact of education on consumer acceptance of the facility. Hence, banks might work on improving education platforms through the inclusion of related literacy programmes of the products. Besides, banks might share their product offerings via social media platforms to breed awareness for adoption. 
Amin, Suhartanto, Ali, Ghazali, Rizal, \& Abdul Razak | Maqasid-based Consumer Preference Index for Tawarruq Personal Financing

Table 4. Factor Analysis and Reliability Test

\begin{tabular}{|c|c|c|c|}
\hline Battery items & F1 & $\mathrm{F} 2$ & F3 \\
\hline $\begin{array}{l}\text { believe that Islamic banks provide clear fatwa } \\
\text { information for tawarruq personal financing products }\end{array}$ & .870 & & \\
\hline $\begin{array}{l}\text { I believe that Islamic banks provide clear adverts for } \\
\text { tawarruq personal financing products }\end{array}$ & .855 & & \\
\hline $\begin{array}{l}\text { I believe that Islamic banks provide continuous publicity } \\
\text { for tawarruq personal financing products }\end{array}$ & .800 & & \\
\hline $\begin{array}{l}\text { I believe that Islamic banks provide a consumer education } \\
\text { for Tawarruq personal financing products }\end{array}$ & .782 & & \\
\hline $\begin{array}{l}\text { I believe that Islamic banks provide sufficient disclosure } \\
\text { for tawarruq personal financing products }\end{array}$ & .753 & & \\
\hline $\begin{array}{l}\text { I believe that Islamic banks have avoided unfair conflicts } \\
\text { with customers of tawarruq personal financing products }\end{array}$ & & .851 & \\
\hline $\begin{array}{l}\text { I believe that Islamic banks have practised price fairness } \\
\text { for tawarruq personal financing products }\end{array}$ & & .831 & \\
\hline $\begin{array}{l}\text { I believe that Islamic banks have offered a fair contract of } \\
\text { tawarruq personal financing products }\end{array}$ & & .825 & \\
\hline $\begin{array}{l}\text { I believe that Islamic banks have considered Shariah as a } \\
\text { comprehensive law for tawarruq personal financing } \\
\text { products }\end{array}$ & & .807 & \\
\hline $\begin{array}{l}\text { I believe that Islamic banks have practised tawarruq } \\
\text { personal financing products that free from negative } \\
\text { elements like riba }\end{array}$ & & .733 & \\
\hline $\begin{array}{l}\text { I believe that Islamic banks have guarded the welfare of } \\
\text { customers via effective customer service }\end{array}$ & & & .770 \\
\hline $\begin{array}{l}\text { I believe that Islamic banks have offered tawarruq } \\
\text { personal financing products that benefit the public more }\end{array}$ & & & .755 \\
\hline $\begin{array}{l}\text { I believe that Islamic banks provide a financing facility } \\
\text { where the funds are drawn from zakat and waqf }\end{array}$ & & & .726 \\
\hline $\begin{array}{l}\text { I believe that Islamic banks have met the basic need of } \\
\text { homeownership via an offer of competitive products }\end{array}$ & & & .712 \\
\hline $\begin{array}{l}\text { I believe that Islamic banks have protected the interest of } \\
\text { shareholders through Islamic investment in the area of } \\
\text { tawarruq personal financing products }\end{array}$ & & & .698 \\
\hline Eigenvalue & 6.145 & 4.342 & 2.978 \\
\hline Variance explained & 38.22 & 22.10 & 11.711 \\
\hline Kaiser-Meyer-Olkin Measure of Sampling Adequacy & \multicolumn{3}{|c|}{0.944} \\
\hline Bartlett's Test of Sphericity & \multicolumn{3}{|c|}{$\begin{array}{c}X^{2}=11614.679(\mathrm{df} 190, \text { Sig } \\
0.000)\end{array}$} \\
\hline Cronbach's alpha & 0.880 & 0.883 & 0.904 \\
\hline
\end{tabular}


Amin, Suhartanto, Ali, Ghazali, Rizal, \& Abdul Razak | Maqasid-based Consumer Preference Index for Tawarruq Personal Financing

Table 5. Maqasid Consumer Preference Index (MCPi) for Tawarruq Personal Financing

\begin{tabular}{lcccccccc}
\hline No. Islamic banks & \multicolumn{2}{c}{ EC } & \multicolumn{2}{c}{ EJ } & \multicolumn{2}{c}{ PW } & MCPi & Ranking \\
\hline & CBM & $\bar{x}$ & CBM & $\bar{x}$ & CBM & $\bar{x}$ & - & - \\
\cline { 2 - 9 } 1. Al-Rajhi Bank & 1.1748 & 3.56 & 1.1484 & 3.48 & 1.1594 & 3.41 & 3.4826 & 5 \\
2. Bank Islam Malaysia & 1.2639 & 3.831 .1946 & 3.62 & 1.2104 & 3.56 & 3.6689 & 1 \\
Berhad & & & & & & & \\
3. Bank Muamalat & 1.1781 & 3.571 .1781 & 3.57 & 1.1594 & 3.41 & 3.5156 & 3 \\
4. CIMB Islamic & 1.1781 & 3.57 & 1.1781 & 3.57 & 1.1662 & 3.43 & 3.5224 & 2 \\
5. Kuwait Finance House & 1.1286 & 3.42 & 1.1253 & 3.41 & 1.1492 & 3.38 & 3.4031 & 7 \\
6. Maybank Islamic & 1.1748 & 3.56 & 1.155 & 3.50 & 1.1730 & 3.45 & 3.5028 & 4 \\
7. RHB Islamic & 1.1517 & 3.49 & 1.1319 & 3.43 & 1.1560 & 3.40 & 3.4396 & 6 \\
\hline
\end{tabular}

Table 5 reports that three banks are committed to Establishing Justice to gain loyalty among their customers to improve the customer base and later their profit. The banks are Bank Islam Malaysia Berhad (3.62), followed by Bank Muamalat (3.57) and CIMB Islamic (3.57). Mohammed et al. (2008) and Amin et al. (2014) assert that justice is imperative for Islamic banks to establish fair dealings with their customers. In the present study's context, however, banks might develop a code of conduct to promote fair dealings, affordable financing packages, and the elimination of injustices.

As for Promoting Welfare, it is found that Bank Islam Malaysia Berhad, Maybank Islamic, and CIMB Islamic are ranked first, second, and third, respectively. This finding is following earlier works by Chapra (2000) and Dusuki (2008) who assert the significance of socio-economic justice and the public's welfare in Islamic banks to actualise the maqasid al-Shariah for Shariah compliance. The banks prioritise welfare through effective customer services, safeguarding the banks' profit without compromising social obligation, offering affordable financing products drawn from endowment funds, the fulfilment of basic needs, and the protection of the banks' shareholders through permissible profit generation via tawarruq personal financing. Going forward, it is suggested that bank managers should consider the poor and needy groups when offering the facility and for that, waqf-based personal financing can be proposed to meet the group's needs.

Given the MCPi, a total of 7 Islamic banks have been examined equally in this study. Bank Islam Malaysia Berhad is relatively better as compared to other banks, followed by CIMB Islamic, Bank Muamalat and Maybank Islamic, among others. Other banks are mapped within the moderate MCPi score. 
Amin, Suhartanto, Ali, Ghazali, Rizal, \& Abdul Razak | Maqasid-based Consumer Preference Index for Tawarruq Personal Financing

\subsection{Analysis}

Generally speaking, this study has proven that the maqasid approach is valid and relevant when explaining consumer behaviour of tawarruq personal financing. The current work has extended the applicability and the generalisation of the Abu Zahrah (1997) in which the three maqasid al-Shariah namely education, justice and welfare are confirmed significant in defining their perceptual behaviours on tawarruq personal financing. The basis of the theoretical framework sourced from the theory has helped improve our understanding pertinent to the factors that influence consumer behaviour of tawarruq personal financing. Earlier works by Amin et al. (2014) and Amin (2017) have demonstrated the significance of the maqasid al-Shariah as essential to determine the receptiveness of Islamic home financing products. Though interesting these studies have confined and narrowed their perspectives on the product whilst the consideration of tawarruq personal financing is limited.

Though Ahmed (2011) argues that tawarruq personal financing does conform to the legal form and not meeting the substance of the Shariah or serve social needs. Ahmed (2011) asserts it as a pseudo-Islamic product. His argument is somewhat in tandem with the current finding indicating that the scores obtained are relatively moderate, ranged from a low of 3.00 to a high of 3.75 . This product is somewhat only able to meet the need of bank customers who possess consistent monthly income, civil officers and affluent folks, to mention some. The considered objectives of maqasid al-Shariah are still minimal and poorly established. In short, pseudo-Islamic products are only meeting the legal form, whilst social needs are relatively lacking. tawarruq personal financing has viewed to meet the need of a certain group of people who has the aptitude of permanent income cash inflow whilst those needy and poor folks are unable to do so owing to poor employment and lack of creditworthiness.

Moreover, three constructs' items are developed properly with the help of 5 interviews with Shariah scholars, who are also lecturers at a public university in Malaysia. We have confirmed that Churchill Jr (1979) is relatively relevant in our context, proving the five items extracted for each factor are fruitful in explaining consumer behaviour of tawarruq personal financing. Two approaches introduced by Churchill Jr (1979) are found valid in the present work in divulging the five items for each dimension or factor. In more detail, we have developed new items that capture the specific context of tawarruq personal financing, which is yet studied in earlier works of Islamic financing in the context of Islamic banking products in Malaysia (Md Taib et al., 2008). Educating Customer, Establishing Justice and Promoting Welfare that describe maqasid al-Shariah for tawarruq personal financing are valid and justified in 
Amin, Suhartanto, Ali, Ghazali, Rizal, \& Abdul Razak | Maqasid-based Consumer Preference Index for Tawarruq Personal Financing

the current context. The current study reveals that these four concepts are imperative, consistent with the finding of Mohammed et al. (2008) who use maqasid al-Shariah when measuring the actual objectives of Islamic banks, so lengthens the application of the maqasid theory to include consumer behaviour of tawarruq personal financing.

Our results indicate that the 7 examined banks have placed a minimal effort in the inclusion of maqasid al-Shariah in their business operations including tawarruq personal financing. Though maqasid al-Shariah is not a requirement to validate the tawarruq personal financing transactions (Bakar, 2016), relatively it is still important to ensure the offered can promote the inclusion of educating public pertinent to the facility, the formation of the shaped justice and importantly the development of welfare that benefits the many. The findings suggest all banks involved have a moderate score for the MCPi, implying there is a need to proactively promote maqasid al-Shariah in their offerings. The current efforts are still minimal and for that changing the product landscapes through proper research and collaboration can be thought of to acknowledge maqasid al-Shariah in their offerings. Following Chapra (2000), maqasid al-Shariah is one of the ingredients in ensuring the successful offered tawarruq personal financing and because of that critical applications of the approach is of utmost importance. Consequently, it helps improve the competitive advantage of tawarruq personal financing, at least.

\subsection{Implication}

This section consists of a critical discussion on the contributions - broken down into three sections. The details are provided.

\subsubsection{Theoretical Implications}

This study offers a new approach in measuring consumer behaviour of tawarruq personal financing by the establishment of a pragmatic approach to guide theory development and to provide a common frame of reference which to integrate various research streams in the context of tawarruq personal financing. Our study has adopted the Abu Zahrah (1997) theory in our attempts to explain consumer behaviour. Even though this approach is relatively new and provides interesting results, revealing Educating customer, Establishing justice and Promoting welfare are explicitly significant to determine consumer behaviour, driven from the examination of the details directed in introducing the approach in the context of tawarruq personal financing. Our empirical findings add new knowledge to the limited body of knowledge presently available in the context of tawarruq personal financing. 
Amin, Suhartanto, Ali, Ghazali, Rizal, \& Abdul Razak | Maqasid-based Consumer Preference Index for Tawarruq Personal Financing

\subsubsection{Methodological Implications}

To our knowledge, this study is the first of its kind to extend the applicability of the MCPi to capture tawarruq personal financing. Previous research has reflected a limited theoretical perspective and has overlooked important theories from Islamic perspectives owing to the difficulty in the conceptualisation and operationalisation of the dimensions capturing MCPi. The current work contributes to the literature in two ways. First, we propose that the dimensions' items are multidimensional to capture different property of knowledge by respondents addressed in the current study. Second, applying maqasid al-Shariah through the MCPi that leads to improved operationalization of the dimensions' items is valid and therefore extending the applicability of maqasid al-Shariah to include tawarruq personal financing.

\subsubsection{Practical Implications}

In terms of practical implications, the results can be employed to guide managers whose objective is to promote consumer selection of tawarruq personal financing in their Islamic banks. First, it has been shown that the three dimensions related (Education, Justice and Welfare) are predictors of consumer behaviour. Thus, managers might consider new etiquette related to maqasid al-Shariah, as one of the common procedure needed to ensure the offered tawarruq personal financing is of value in providing new knowledge to bank customers along with proper assistance of justice and welfare if necessary. Second, it has been shown in this study, results obtained for all banks are typically moderate. Though their influence is somewhat marginal, the impact can be greater if certain formality is established and facilitated. It might be possible to inculcate maqasid al-Shariah through the publication of the merits drawn from the dimensions embedded to tawarruq personal financing. Third, managers are also guided to ensure the resources related can be optimized to ensure the offered successfully. These include effective personnel for customized services and an online information centre to support potential and repeat customers.

\section{Conclusion and Recommendation}

\subsection{Conclusion}

It is worth noting that the present study proves the applicability of the maqasid al-Shariah to explain consumer behaviour of tawarruq personal financing, through the formation and development of MCPi, specifically capturing the current's context. We have confirmed the validity of the MCPi in the current context through the positivism approach, where the questionnaire survey is brought into play. A total of 7 Islamic banks have been 
Amin, Suhartanto, Ali, Ghazali, Rizal, \& Abdul Razak | Maqasid-based Consumer Preference Index for Tawarruq Personal Financing

included in the analysis via their customers, who have a bank account at least a normal account. All banks under contemplations have a moderate score of the MCPi, implying the maqasid al-Shariah has been applied but a formal effort that makes it mandatory is still at an infancy stage. There is no such requirement to claim 'Islamic banking is Islamic', sufficient only when Islamic banks have met the Shariah compliance as outlined by the National Shariah Advisory Council (NSAC) of Bank Negara Malaysia. At the same time, if such a need is established, the fearing part of individual banks is the costs sparked from the compliance towards maqasid al-Shariah that may erode their profit amount sourced from the offered tawarruq personal financing.

\subsection{Recommendation}

The results obtained provide some actions plan for practitioners' mainly Islamic banks and regulators to design the better offered tawarruq personal financing. Besides, the results offer a new idea to academicians who are eager to undertake an extended study of tawarruq personal financing covering different geographies, countries and the new proposed variables to extend the findings. Concerning Islamic banks, the results indicate that the banks shall develop tawarruq personal financing, where the maqasid "implications" are found and for that better action plans through the enhanced Shariahcompliance practices are developed. These include proper documentation and better advertisement to the targeting customers. Besides, offering tawarruq personal financing funded via sadaqah funds should be prioritised to those poor and needy folks, where the discounted profit rate is offered for improving value-based intermediation, as well as an ummah, improved wellbeing. Concerning the regulator, the outputs obtained from this work can be employed as a general guideline in developing a directive, which is holistic and effective in inculcating the importance of maqasid al-Shariah as another competitive weapon of Islamic banks - complementing the importance of Shariah compliance. Besides, this study can provide important characteristics that can be employed when permitting Islamic banks to arrange their mortgages based on maqasid al-Shariah. In turn, this effort if it is directed properly can lead to the introduction of the maqasid al-Shariah home financing facility, and this is something beautiful in reducing the gaps between Shariah compliancy and Shariah-based products for the industry, at least.

As for academicians, this study offers two perspectives that guide future researchers who are interested to extend our research setting and model. Firstly, our study introduced a new way of gauging consumer preference, where the score rating approach found in the MCPi is introduced and evaluated empirically. Future researchers are expected to extend this approach in different geographies for application and generalisation purposes. Secondly, our study proved the applicability of the maqasid al- 
Amin, Suhartanto, Ali, Ghazali, Rizal, \& Abdul Razak | Maqasid-based Consumer Preference Index for Tawarruq Personal Financing

Shariah, when explaining Islamic banking products' receptiveness as found in the current study, specifically on tawarruq personal financing.

We report two research drawbacks, thought to have an impact on future research direction. First, the current study only examines three dimensions emanated from Abu Zahrah (1997) theory of maqasid al-Shariah. Future studies are encouraged to extend new dimensions and integrated them with Abu Zahrah (1997) for application and generalisation. Second, our geographies are confined to Labuan and Kota Kinabalu in East Malaysia whilst evidence from West Malaysia is still minimal about the research setting and the stored of empirical results. Hence, future studies may consider the inclusion of new cities from West Malaysia and be compared with cities in East Malaysia to extend the research findings.

\section{Acknowledgement}

This study is funded by the Fundamental Research Grant Scheme (FRGS): FRG0438-SS-1/2016, Ministry of Higher Education (MOHE), Malaysia. Many thanks to Sister Z. Anis for her research assistance. Our grateful is also extended to the Editor, Dr Ascarya, the Managing Editor, Dr Dimas Bagus Wiranatakusuma and the Editorial team of the Journal for their brilliant publication supports. 
Amin, Suhartanto, Ali, Ghazali, Rizal, \& Abdul Razak | Maqasid-based Consumer Preference Index for Tawarruq Personal Financing

\section{References}

Ab Rahman, A., Mohamad, S., \& Salleh, I. M. (2010). Bay 'al-tawarruq dan aplikasinya dalam pembiayaan peribadi di Bank Islam Malaysia Berhad. Jurnal Syariah, 18(2), 333-360.

Abdul Rahman, Z. N., \& Ab Manan, S. K. (2014). Tawarruq as a useful instrument to finance retail the halal way. Procedia-Social and Behavioral Sciences, 121, 281-290.

Abdullah Thaidi, H. A., Ab Rahman, M. F., \& Ab Rahman, A. (2014). The analysis of gharar existence in the implementation of tawarruq personal financing. Global Journal Al-Thaqafah, 4(1), 83-95.

Abu Zahrah, M. (1997). Usul al-Fiqh. Cairo: Dar al-Fikr al-'Arabi.

Ahmad, E. F., Shihama, M., Mohamad Tarmizi, N. A., Jibril, S. M., Djama, S. I. , \& Muneeza, A. (2017). Tawarruq as a product for financing within the Islamic banking system: a case study of Malaysian Islamic banking system. International Journal of Management and Applied Research, 4(1), 31-43.

Ahmed, H. (2011). Maqasid al-Shariah and Islamic financial products: a framework for assessment. ISRA International Journal of Islamic Finance, 3(1), 149-160.

Ali, M. M., \& Hassan, R. (2016). Determinants of Shariah non-compliant events in Islamic banks in Malaysia: with special reference to tawarruq-based financing. Al-Shajarah: Journal of the International Institute of Islamic Thought and Civilization (ISTAC), 21(3), $217-221$.

Ali, M. M., \& Hassan, R. (2020). Survey on Shariah non-compliant events in Islamic banks in the practice of tawarruq financing in Malaysia. ISRA International Journal of Islamic Finance, 12(2), 151-169.

Ali, M., Raza, S. A., Puah, C. H., \& Karim, M. Z. A. (2017). Islamic home financing in Pakistan: an SEM-based approach using modified TPB model. Housing Studies, 32(8), 1156-1177.

Alkhan, A. M., \& Hassan, M. K. (2019). Tawarruq: controversial or acceptable? Arab Law Quarterly, 33(4), 307-333.

Amin, H. (2017). Consumer behaviour of Islamic home financing: investigating its determinants from the theory of Islamic consumer behaviour. Humanomics, 33(4), 517-548.

Amin, H. (2019). Understanding consumer receptiveness of mortgage-based Islamic social finance using a maqasid framework: a preliminary study. International Journal of Islamic Economics \& Finance (IJIEF), 2(1), 4772. 
Amin, Suhartanto, Ali, Ghazali, Rizal, \& Abdul Razak | Maqasid-based Consumer Preference Index for Tawarruq Personal Financing

Amin, H., \& Abdul Hamid, M. R. (2018). Patronage factors of tawarruq home financing in Malaysia. International Journal of Business and Society, 19(3), 660-677.

Amin, H., \& Chong, R. (2011). Is the theory of reasoned action valid for ArRahnu? An empirical investigation. Australian Journal of Basic and Applied Sciences, 5(10), 716-726.

Amin, H., Abdul Rahman, A. R., \& Abdul Razak, D. (2013). An integrative approach for understanding Islamic home financing adoption in Malaysia. International Journal of Bank Marketing, 31(7), 544-573.

Amin, H., Abdul Rahman, A.R., \& D. Abdul Razak. (2014). Consumer acceptance of Islamic home financing. International Journal of Housing Markets and Analysis, 7(3), 307-332.

Amin, H., Ghazali, M., \& Supinah, R. (2010). Determinants of qardhul hassan financing acceptance among Malaysian bank customers: an empirical analysis. International Journal of Business and Society, 11(1), 1-16.

Bakar, M.D. (2016). Shariah Minds in Islamic Finance, Kuala Lumpur: Amanie Media.

Chapra, M.U. (2000). The Future of Economics: An Islamic Perspective. United Kingdom: The Islamic Foundation.

Churchill Jr, G. A. (1979). A paradigm for developing better measures of marketing constructs. Journal of marketing research, 16(1), 64-73.

Cochran, W.G. (1963). Sampling Technique, New York: Wiley.

Dusuki, A. W. (2010). Bursa Malaysia's Suq Al-Sila'(Commodity Murabahah House) as an alternative platform for tawarruq transaction. The Journal of Muamalat and Islamic Finance Research, 7(1), 147-167.

Dusuki, A.W. (2008). Understanding the objectives of Islamic banking: a survey of stakeholders' perspectives. International Journal of Islamic and Middle Eastern Finance and Management, 1(2), 132-148.

Hassan, R. (2014). Corporate Governance Practice in Islamic Financial Institutions, Kuala Lumpur: IBFIM.

Hwang, C. L., \& Yoon, K. (1981). Multiple criteria decision making. Lecture Notes in Economics and Mathematical Systems, 186, 58-191.

Iqbal, Z., \& Mirakhor, A. (2011). An Introduction to Islamic Finance: Theory and Practice, New York: Wiley.

Khan, F. (2014). The framework for an Islamic theory of consumer behaviour. Journal of Islamic Business and Management, 4(1), 17-54.

Khan, M.F., \& Ghifari, N.M. (1992). Shatibi's objectives of Shariah and some implications for consumer theory. In Sadeq, A.M., \& Ghazali, A. (eds.). 
Amin, Suhartanto, Ali, Ghazali, Rizal, \& Abdul Razak | Maqasid-based Consumer Preference Index for Tawarruq Personal Financing

Readings in Islamic Economic Thought. ( 176-202). Kuala Lumpur: Longman Malaysia.

Mahyudin, M. I., \& Che Seman, A. (2014). Bay 'al-tawarruq dan aplikasinya di Bank Muamalat Malaysia Berhad. Journal of Muamalat and Islamic Finance Research, 11(1), 75-96.

Mahyudin, M.I., \& Che Seman, A. (2018). The application of bay' altawarruq in Islamic banking institutions in Malaysia, Rahman, A.A. (Ed.) New Developments in Islamic Economics, Emerald Publishing Limited, 169-179.

Md Taib, F., Ramayah, T., \& Abdul Razak, D. (2008). Factor influencing intention to use diminishing partnership home financing. International Journal of Islamic and Middle Eastern Finance and Management, 1(3), 235-248.

Mohammed, M.O., Abdul Razak, D., \& Md Taib, F. (2008). The Performance Measures of Islamic Banking on The Maqasid Framework. Paper presented at IIUM International Accounting Conference (INTAC IV). Organised by International Islamic University Malaysia, Putra Jaya.

Muneeza, A., Hassan, R., \& Wisham, I. (2011). Islamic Banking under the Malaysia Law. Kuala Lumpur: A.S. Noordeen.

Sekaran, U., \& Bougie, R. (2010). Research Methods for Business: A Skill Building Approach (5th edn.), West Sussex: John Wiley and Sons. 
Amin, Suhartanto, Ali, Ghazali, Rizal, \& Abdul Razak | Maqasid-based Consumer Preference Index for Tawarruq Personal Financing

This page is intentionally left blank.

International Journal of Islamic Economics and Finance (IJIEF), 5(1), 1-30 30 